\title{
A critique of approaches: a review
}

\author{
K. S. Murty and A. C. Bouquet, Studies in the Problems of Peace
}

\section{ROBERT I. CRANE}

\section{Mental Health Research Institute, The University of Michigan}

I must confess I approached this book (1) with mixed feelings. On the one hand, the plethora of published materials on peace made one dubious that further spillage of ink could be singularly profitable; on the other hand, there seemed to be the possibility that an enterprise involving scholars from two different parts of the world might contribute a fresh insight into the tasks at hand if peace is to be obtainable. I regret to say that reading the book has confirmed the initial fears and disappointed hopes. Having pronounced what must seem to be a harsh dictum, I hasten to indicate the reasons for my reaction.

A great deal has been said about peace, but most of it has revolved around certain fancies, prejudices, instances of folk wisdom, and dogmas long held and widely repeated. One of the problems of peace would seem to be the fact that each individual is his own authority on the subject, bringing to bear his own whims. It can, I think, be argued that intellectual and scientific progress are not liable to be made in this fashion.

In the first part of the volume under review, Mr. Bouquet essays a chronicle of the intellectual history of ideas about peace and war and of ideas about how to attain peace by one formal mechanism or another. He stumbles into the same pit which has dogged the footsteps of most intellectual historians: a tenacious desire to trace the thread of certain ideas through their long and tortured history, commenting on each successive transformation of the germ of the idea as it was reshaped in the hands of successive "thinkers." Thus, for example, we are treated to an exposition of ancient Chinese ideas about peace, contrasting the opinions of Confucius with those of Mencius or of Mo $\mathrm{Ti}$ (the latter being quoted at considerable length). Presumably the aim of this disquisition is to get men of good will to recall what other men of good will have said in the past.

Mr. Bouquet seems to be particularly encouraged when he can discover an additional figure from antique times who has pronounced in favor of good will. Thus, he resurrects Zeno who, it is said, came to the idea of universal brotherhood and who, in Tarn's opinion, got the idea from Alexander the Great. Mr. Bouquet turns next to an exposition of Islamic ideas about peace and war and then to medieval Christian opinions. $\mathrm{He}$ discovers that a medieval jurist, Pierre du Bois, made the first actual attempt to draw up a European peace plan and that Dante, in his de Monarchia laid down basic principles regarding the necessity for a federal super-state to achieve peace. (Inci- 
dentally, Mr. Bouquet-true to the traditions of intellectual history-cannot resist an aside to establish the correct date of publication of the de Monarchia.)

This progression from idea to idea carries us through the Quakers, Charles Rene Castel de St. Pierre, Grotius, and others; de St. Pierre being awarded the palm for originating the idea which later took shape in the International Court at the Hague. $\mathrm{He}$ also discusses at some length Kant's scheme for establishing peace. Perhaps I need only add that $\mathrm{Mr}$. Bouquet has done, in good style, in 110 pages what was accomplished by Edith Winner and Georgia Lloyd in 378 pages in Searchlight on Peace Plans (2). In his summary to the first part of the book, Mr. Bouquet makes the following comment:

But why should such weapons, as for example, long-range ballistic missiles ever be needed? On the major issue, if one half of the world were to give up adhering obstinately to Marxist fundamentalism, and the other half, and especially its largest element, were to take a less prejudiced view of what is involved in abolishing poverty and exploitation, and in creating a welfare state, with a decent standard of living for all, there would be mighty little excuse for any wars [pp. 117-8].

The second part of the book is by Dr. K. S. Murty and is, in essence, an informed philosophical discussion of a variety of problems concerned with peace and war, viewed as an idea or a frame of mind or an instinct or a set of acquired drives. In the process Dr. Murty reviews and analyzes classical Hindu thought on the theory of just war and the development of Hindu philosophy regarding violence. He also discusses the Hindu concept of the State and indicates how, in his judgment, the Hindu concept of the State has had disastrous consequences for the maintenance of peace. This leads to an extensive discussion of the philosophical implications of the doctrine of ahimsa (non- injury) which is traced through all of its classical expositions by various Hindu and western thinkers. (Interestingly enough, Dr. Murty delivers himself of some incidental but cogent criticisms of the assumptions underlying Gandhi's non-violent philosophy.)

Dr. Murty turns next to a discussion of philosophies of violence and war, examining in turn the views of the Spartans, of Plato, Machiavelli, Bodin, von Clausewitz, and Nietzsche. Of Nietzsche, Dr. Murty has the following to say:

I do not like Nietzsche's ethics; I consider the Buddhist and the Christian systems of ethics as being more in tune with reality and truth. But I do not see how the one can be disproved and the other proved empirically. If Nietzsche's premises are granted, his morality follows; but they are neither necessary, nor provable. It is true, as Nietzsche says, that in all men there is an instinct for self-assertion and a will to power; but he forgets that there are several other instincts and desires, conscious and unconscious, in man. Some of these instincts contradict the others; human personality is not uniform, but complex [p. 230].

I quote this passage, I hope not unfairly, because part of my objection to the book is bound up with its message. I think it is quite irrelevant to the subject of peace and war what Nietzsche's ethics were or, for that matter, what Buddhist or Christian ethics are. The undergraduate who has just come across Tawney may think he has discovered the key to wisdom when he discerns that there was some kind of a link between Protestantism and Capitalism, but more mature judgment warns that these links between systems of ideas and patterns of national behavior are tenuous at best, subject to varied interpretation, and seldom supported by facts.

Dr. Murty then turns to a discussion of the causes of war. He asks whether war is rooted in human nature and, after reviewing the literature, decides that such is not 
proven to be the case. Next, he asks whether one can believe in the existence of "instincts" such as pugnacity. Here he weighs the opinions of various psychologists on the matter of instincts, and decides that the theory of innate instincts is probably incorrect. $\mathrm{He}$ cites several reasons for this opinion, relying heavily upon what might be called the position of cultural relativism. He also discusses and evaluates the "tension" theory, said to have been originated by Pierre Janet and carried forward by Kurt Lewin and the UNESCO. But Dr. Murty is not satisfied with "tension" theory either. On the matter he says:

The fundamental objection to this approach seems to be that an understanding of individual hostility cannot help us to understand group or national antagonisms and that individual frustrations cannot serve as explanations of wars. The majority of individuals in all nations do not know anything about other nations. . . . Their fields of motivations do not extend beyond their occupations and their communities. It is ridiculous to believe that the tensions that may exist among them have anything to do with wars between nations. It is the political views of a few persons, and not the tensions among people, which shape international policies [p. 294].

While we may all agree with the comment just quoted, it cannot help us to arrive at a more effective view of the circumstances which lead to peace or to war. One asks, therefore, what Dr. Murty would substitute for the approaches he has criticized. His position rests, in the last analysis, upon a belief in cultural relativism (that much that we see in man is the result of acquired habits and his own distinctive culture) and a judgment that war is a "social pattern," or a social institution. The task, then, is to change the social pattern away from reliance upon war.

Dr. Murty argues that what is needed is the "evolution of an appropriate political and social organization in all countries." In his view, we must have a new world order based upon informed public opinion and good faith. Recognizing that this will take some time, he suggests an interim development by which the enlightened nations, such as Sweden, Switzerland and Denmark, will see to it that the "two power blocs are reconciled to each other" by two measures: "(a) by bringing about an equilibrium which will enable both sides to make concessions, or (b) by helping both the sides to modify the values they stand for so that gradual coalescence may be possible. ..." (p. 319). He also proposes that intellectuals and scientists should work as individuals with a sense of responsibility for social welfare toward the creation of an international, intellectual Respublica litteraria. In his opinion, such an informal cooperation among scholars of all nations could rise above national prejudices and act as a world conscience. In his words, "the Respublica litteraria must be prepared to defy governments in power and even the law of the country, if the interests of truth and humanity demand them. . . . The Respublica litteraria would consist of men who can put the interests of truth, justice, and humanity above the interests of their countries and races. . . " (pp. 341-2).

Surely no one can object to the demand that men of intelligence aspire to standards of judgment not swayed by partisan passions. Only the very churlish would take issue with Dr. Murty's proposal for an independence of judgment and spirit by savants. But, unfortunately, the history of the human race tells us that noble souls and minds do not necessarily sway the course of events. Just as one can express some doubt that the uncommitted nations can move the great powers to a reconciliation, so can one express a doubt that the problem of peace can be solved by the immolation of savants willing to defy their governments when they 
think their governments are wrong. Perhaps, at best, Dr. Murty's council is a council of despair. But, whether it is or not, it rests, I think, upon assumptions about the problem of peace which are rather unconvincing. Can it be that that is the problem of peace?

\section{REFERENCES}

1. Murty, K. Satchidananda and Bouquet, A. C. Studies in the Problems of Peace. Bombay: Asia Publishing House, 1960.

2. Winner, Edith and Lloyd, Georgia. Searchlight on Peace Plans. New York: E. P. Dutton \& Co., 1944. 